\section{Grazing Intensity and Forage Quality on the Arizona Strip}

\author{
ART MEEN
}

$\mathrm{T}$

The level of forage utilization in a pasture can have a large influence on the available diet quality for cattle. This influence can be seen in three ways:

1) As preferred forages are used up first, they become less and less available for consumption.

2) As the forage is used up in the most accessible areas of a pasture, forage availability will begin to limit actual forage intake by cattle.

3) The dietary quality of an individual plant species can be quite different depending on whether cattle are grazing it for the first time, or whether they are returning to graze it for the second or third time.

This study addresses the third variable, quantifying dietary quality at different levels of utilization. Four key forage species were evaluated: fourwing saltbush, Indian ricegrass, galleta, and tall wheatgrass. Each species will be discussed separately.

Included in Figures 1, 2, and 3 are lines showing the "typical" nutrient requirements ${ }^{1}$ of a mature cow of average size that calves in March-this line is not specific to all herds. The requirement line assumes no net weight loss or gain by the cow, except for the fetus.

\section{Methods}

Beginning in October 1998, samples of the key species were collected monthly for 12 months at three levels of utilization and analyzed for crude protein (CP), total digestible nutrients (TDN, or energy), and phosphorus (P). Each sample was clipped as though an animal had grazed the key species on 3 separate occasions. The utilization levels for the samples were the first $30 \%$ of available plant material (light use), the next $30 \%$ of available plant material (moderate use), and the remainder of the plant's growth (heavy or severe use). All samples were taken from the current season's growth. During the winter, samples were selected from the most recent growth available. The plants chosen for sampling each month had not been grazed or clipped in the current growing season. The 3 range forages were sampled on a Gypsum Upland range site in a 7" to 11" precipitation zone in Major Land Resource Unit (MLRU) D35-4, Colorado Plateau Cold Desert Grassland. Tall wheatgrass was sampled from the irrigated fields near Fredonia, Arizona. The clipped levels of utilization were estimated visually and were not weighed.

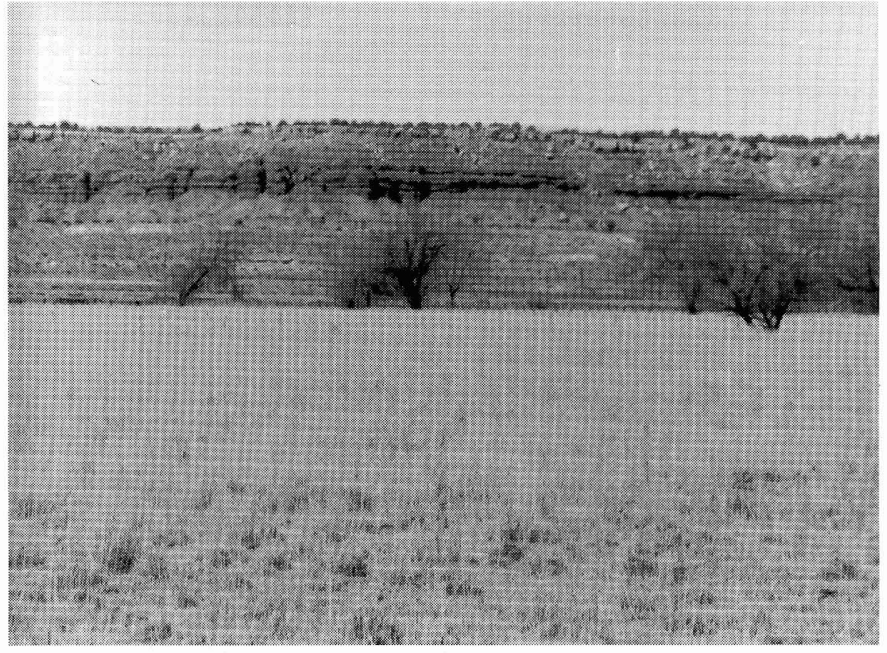

Tall wheatgrass fields at Fredonia.

\section{Results and Discussion}

\section{Fourwing Saltbush (Atriplex canescens)}

Fourwing saltbush is an important browse species. It is grazed year round for forage, and utilization levels are often heavy during the winter and early spring. Cattle generally select the most recent growth leaders and leaves first, gradually working their way into older woody material until, at severe levels of utilization, stems the size of pencils are consumed.

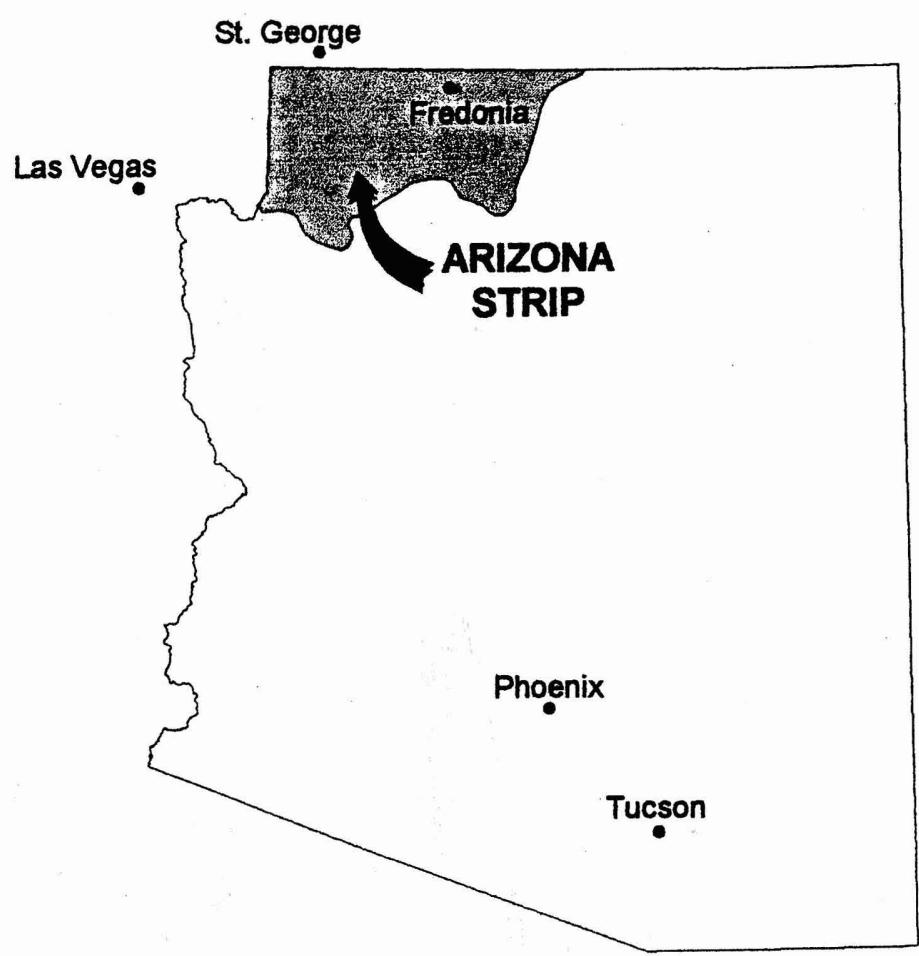




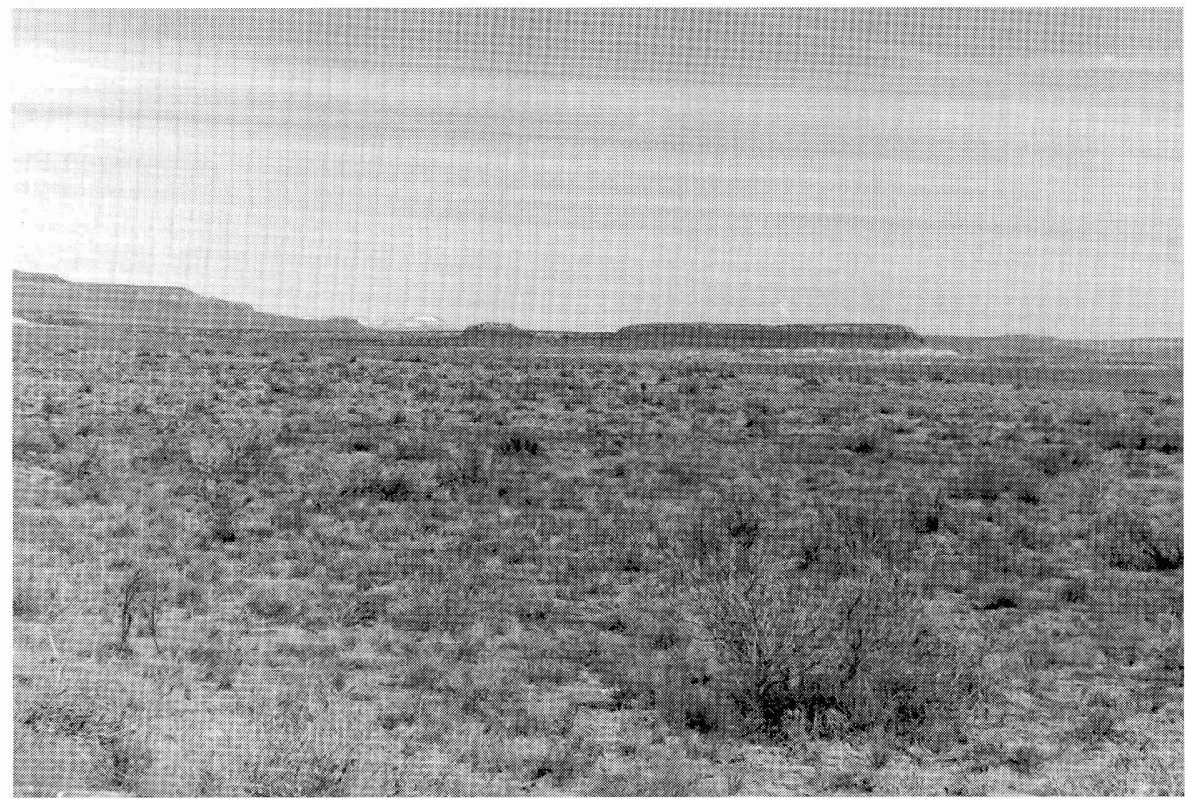

Gypsum upland range site.

Results show a difference in crude protein $(\mathrm{CP})$ content at different utilization levels (Figure 1). At light use, CP was consistently the highest regardless of the time of year. At moderate use, $\mathrm{CP}$ content was reduced by an average of $17 \%$, while for the samples representing heavy use, the $\mathrm{CP}$ content dropped about $30 \%$. It is noteworthy that fourwing saltbush has a fairly high CP content even when it has been heavily used. Perhaps this explains its heavy use during winter months on many ranges even when there is ample dry grass available.

The energy content of fourwing saltbush shows a similar pattern. Moderate-use and heavy-use portions of the plant contained an average of $5 \%$ and $12 \%$ less TDN, respectively, than the first $30 \%$ of available forage. The difference in TDN among the levels of use appears to be smaller, and energy content seems to fluctuate much less than protein content. This is consistent with the results from an earlier forage analysis study done on the Arizona Strip. ${ }^{2}$ The previous study had also shown a high energy content in fourwing saltbush and

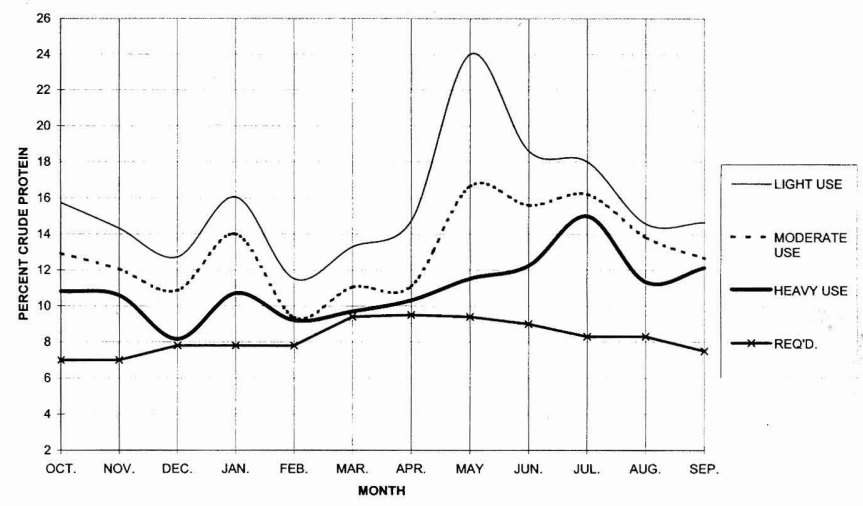

Fig. 1. Crude protein content of fourwing saltbush at three utilization levels. other browse species. This information indicates that even at heavy levels of utilization, fourwing saltbush is a good source of energy.

The phosphorus levels in fourwing saltbush showed similar patterns for different levels of use. Phosphorus appears to peak and decline at the same time as crude protein, matching the plant's growth curve very closely.

\section{Indian Ricegrass (Achnatherum hy- menoides)}

This species was chosen for sampling as being representative of cool-season grasses in the area. At high-desert elevations, Indian ricegrass begins spring growth in March and grows actively through April. Flowering begins in mid-May; seed set starts by the end of May and it matures through late June. During the summer months there is little plant growth although the earlier growth may retain some green color. Late summer and early fall moisture will initiate a small amount of leaf growth. This species was sampled from the top down. The sample taken to represent light use was approximately the top $1 / 2$ of standing growth. The sample for moderate use was the next $1 / 4$ of growth down to a stubble height of 2-3 inches. The final sample was the remainder of standing growth down to a stubble height of about $1 / 2$ inch. The only exception to this came during March, when the sample for light use was composed entirely of the new leaves just emerging from last year's stubble.

During the growing season the crude protein content of Indian ricegrass is significantly higher at light use levels than it is at moderate or heavy levels of use, and it meets a cow's requirements for a longer period of time. There is little difference among the use levels during the winter dormant period.

The TDN content of Indian ricegrass showed a difference between light use and the other use levels during the spring growing season. During the summer, fall and winter there does not appear to be much difference among the 3 levels of utilization, although heavy use consistently had the lowest TDN content.

The phosphorus levels in Indian ricegrass appear to follow the plant growth curve, although the figures from this study are not particularly consistent. Phosphorus deficiency is a major concern on the Arizona Strip.

\section{Galleta (Pleuraphis jamesii)}

Galleta is an important forage species on the Arizona Strip and was chosen to represent warm-season grasses. Spring growth begins in April and peaks in May, with flowering and seed set carrying into June. Typically, soil moisture has been used up by then and galleta is semi-dormant (summer slump period) until moisture arrives. Galleta grows quickly in response to summer rain and will sustain growth into October if there is sufficient soil moisture. In a wet summer the quantity 


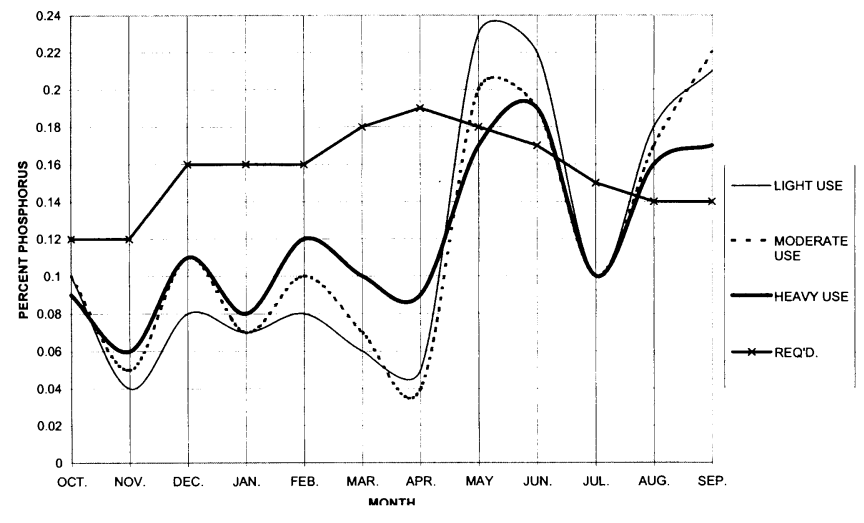

Fig. 2. Phosphorus content of galleta at three utilization levels.

of summer growth can be much greater than during spring. This species was sampled from the top down, in a similar pattern to Indian ricegrass.

During both the spring and summer growing periods the crude protein content was highest in the light-use sample. The moderate-use sample was also higher than the heavy-use sample during these periods. Galleta does not appear to meet cattle protein requirements during the growing season when it is heavily utilized or at times when used moderately. There is little difference among the samples during either the dormant season or the period of summer slump.

The energy content of galleta showed little difference between light use and moderate use at any time of year. The samples representing heavy use appeared to have a little less TDN at all times of the year, but the differences are relatively small. Galleta's TDN content does not vary as much as the crude protein content; this is similar to the pattern observed in the species already discussed, and is consistent with the results from the earlier Arizona Strip forage study.

The phosphorus results for galleta are somewhat variable, but it appears that the basal portion of the plant contains a higher level of $\mathrm{P}$ than the rest of the plant when the plant is dormant, and less when the plant is growing (Figure 2). Only during periods of peak growth does the $\mathrm{P}$ content meet a cow's requirement. This is also consistent with previous work.

\section{Tall wheatgrass (Elytrigia elongata)}

This forage was selected for sampling because it is a common grass in the irrigated pasture fields around Fredonia. It is a cool-season grass that thrives on saline soils and uncertain irrigation. It produces abundant forage, which is coarse and not very palatable when mature and dry. It is commonly harvested as hay for winter-feeding. There is not much fertilizer used on these fields, and the area sampled had not received any supplemental nitrogen or phosphorus for several years.

Tall wheatgrass was sampled somewhat differently than the other grasses during this study. Because of supplemental irrigation water in the fall, it produces growing tillers from October into January, and even through the entire winter if the temperatures stay mild. This growth is slow, but livestock consistently select it above the older material and will graze these tillers severely before they graze the coarse stalks and seed heads from the previous summer. Accordingly, from October through February the samples representing light use consisted entirely of this current growth. Moderate-use and heavy-use samples were the top portion and the bottom portion, respectively, of the mature stalks. From March through June the samples were taken from the top of the plant down, sampling current growth only. By July and for the rest of the summer the current year's seed heads were out of the boot, and so the light-use samples was entirely basal leaves again. The upper halves of the stalks were sampled to represent moderate use and the bottom halves were sampled for heavy use.

During the fall and winter grazing period the new leaf growth represented by the samples for light use proved to have good crude protein content, well above the typical maintenance requirement for cattle calving in March. In marked contrast, the previous summer's standing forage has a CP level much lower and well below what a cow needs. Tall wheatgrass had considerably more growth in March than the cool-season native Indian ricegrass, and all three samples were taken from this growth. The protein peak was very high in all samples in the March-April period and then declined as the growth matured. Typically these fields are cut for hay in the middle of June. An average of June's samples, which were taken just as hay was being cut, suggests a CP content of around $9 \%$ for the hay. This appears to be accurate since a fecal sample from cows fed on this hay in November estimated diet crude protein to be just over 9\%. This suggests that a significantly higher protein content can be achieved by harvesting before June. In August and September the moderateuse samples had higher CP than the leaves. Possibly this is because the samples for moderate use contained the ripening seeds. Also, there is rarely irrigation water at this time of year and leaf growth has stopped on tall wheatgrass unless summer rains are abundant.

During the fall and winter seasons the TDN content of the tiller and leaf growth was higher than the TDN content of the standing forage (Figure 3 ). This difference carried through the spring peak growth period, but there appears to be no differ-

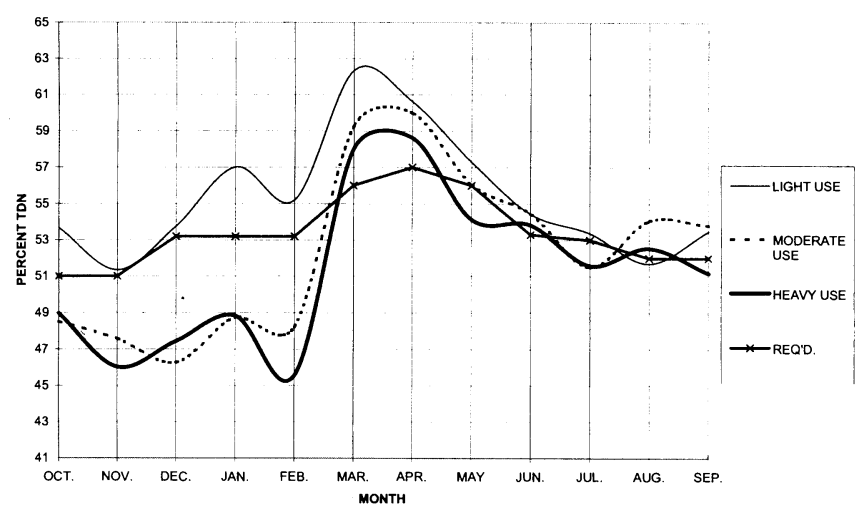

Fig. 3. TDN Content of Tall Wheatgrass at Three Utilization Levels

ence among the samples during the summer. All samples just about met the cow's typical energy requirements from March through September, with little surplus except during peak spring growth. As with the other species sampled, for most of the year tall wheatgrass consistently has the highest phospho- 
rus content in the most recent growth. The exception is during the summer when the moderate-use sample containing the ripening seeds is higher in $\mathrm{P}$. This correlates well with the crude protein content of tall wheatgrass and the observations on patterns of growth.

\section{Summary}

1) During their growing season, the crude protein content of all forages sampled was consistently the highest for light levels of utilization. Forage CP when grazed moderately was usually higher than when grazed heavily, but the difference was smaller and not as consistent.

2) When dormant, the grasses had little difference in CP content among the three levels of use. The differences in $\mathrm{CP}$ content of fourwing saltbush continued throughout the year, although they were smaller during dormancy.

3) Energy content of forage fluctuated less during the year than crude protein content. Differences among the levels of utilization were most apparent during peak growth periods for the grasses, while the differences in the fourwing saltbush samples were evident throughout the year.

4) Forage phosphorus is deficient for much of the year, at least in the species sampled. Phosphorus content follows the plant growth curve closely, and is highest during periods of peak vegetative growth. Phosphorus levels are highest in those parts of the plant that are actively growing.

\section{Conclusions}

The level of utilization in a pasture can significantly affect the available diet quality for cattle. This is especially true for crude protein content. Forage that is heavily grazed may not meet a cow's needs even during times of peak vegetative growth. Monitoring utilization levels and adjusting pasture rotation is as important as matching the cow to the environment or timing the cow's peak requirements to fit with peak forage quality.

\section{References}

${ }^{1}$ National Research Council: Nutrient Requirements of Beef Cattle, $7^{\text {th }}$ ed. National Academy Press, 1996.

${ }^{2}$ Meen, Arthur S: Forage Quality on the Arizona Strip. Fredonia Field Office, USDA-NRCS, 1999.

Cow-Calf Management Guide and Cattle Producer's Library, $2^{\text {nd }}$ ed. Cooperative Extension Service, 1997

Pond, W.G., D.C. Church, and K.R. Pond: Basic Animal Nutrition and Feeding, $4^{\text {th }}$ ed. John Wiley and Sons, 1995.

USDA-NRCS National Range and Pasture Handbook.

Author is with the USDA-NRCS Fredonia Field Office

Funded by: Fredonia Natural Resource Conservation District

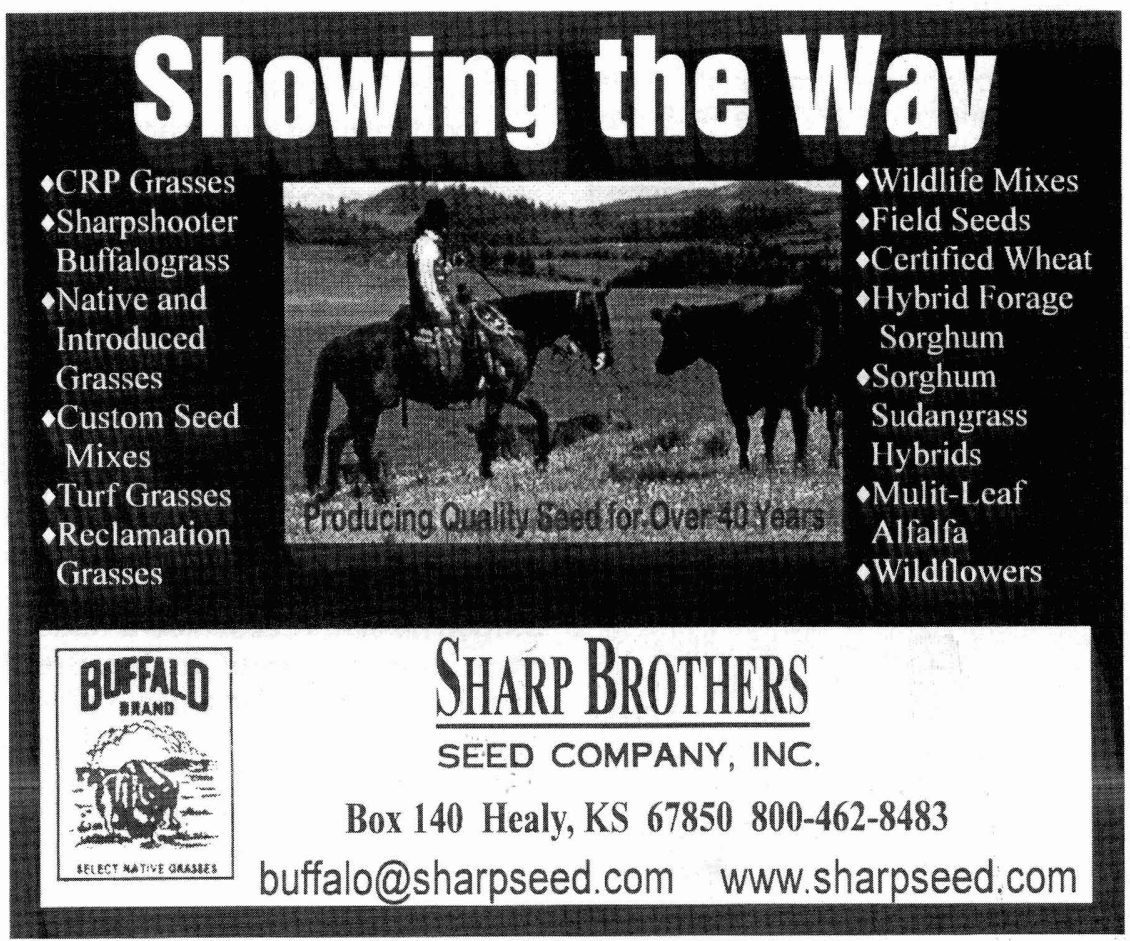

